\title{
De Marias e Luizes Experiências devocionais e de gênero numa festa mariana
}

Eloísa Martín ${ }^{1}$

\section{Introdução}

Itatí é um povoado pequeno da província de Corrientes, no nordeste argentino, situado nas margens do rio Paraná, no limite com Paraguai. O santuário dedicado à Virgem, da qual o povoado adotou o nome, é o maior e o mais importante dessa região, atraindo fieis das províncias vizinhas, e também do Paraguai e de Buenos Aires. ${ }^{2}$

\footnotetext{
${ }^{1}$ Eloísa Martín é doutoranda em Antropologia Social no Museu Nacional/ Universidade Federal do Rio de Janeiro e co-editora executiva de Ciencias Sociales y Religión/ Ciências Sociais e Religião e de Estudios sobre Religión, ambas publicações da Asociação de Cientistas Sociais da Religião no Mercosul. Pesquisa sobre questões relativas à religião desde 1995 e tem publicado artigos na Argentina e no Brasil.

${ }^{2}$ A cidade de Buenos Aires fica a mais de mil quilômetros de Itatí e encontra-se fora da "área de influência" do santuário. No entanto, cada ano em ocasião da festa, milhares de fiéis nascidos no Nordeste Argentino ou filhos e netos deles que moram em Buenos Aires, peregrinam até o santuário.
} 
O santuário, sob custódia da congregação de Dom Orione desde 1936, realiza vários eventos durante o ano, dos quais o mais importante é o do dia 16 de julho, aniversário da coroação pontifícia da Virgem de Itatí. A festa de julho inicia-se no 30 de junho com duas séries de novenas preparatórias e terminam no dia $16 \mathrm{com}$ a chegada de várias peregrinações, uma procissão náutica no Paraná e uma missa celebrada pelo arcebispo de Corrientes, à qual também assistem as autoridades civis e militares da província. Como outras festas de padroeiros, inclui, ademais, um festival de música e dança, organizado pela Igreja, e bailes, feiras e bingos.

O presente artigo parte de uma pesquisa levada a cabo entre 1998 e 2000 nessa festa e que resultou na minha dissertação de mestrado (Martín, 2001). Longe de ser una reflexão acabada, este trabalho pretende ser, apenas, uma longa e ulterior nota de rodapé da mesma, na qual havia analisado a forma pela qual as experiências de três atores típico-ideais da festa - itatenhos, peregrinos e Igreja - são atravessadas por um provincialismo de matriz correntina e decodificadas de forma variável por cada um deles, constituindo, ao mesmo tempo, particularizações da experiência católica na Argentina. Ainda, neste trabalho, proponho uma heterogeneização da "lógica" predominante na relação dos peregrinos com a Virgem.

Os peregrinos se aproximam da Virgem de Itatí e da festa celebrada a cada 16 de julho a partir das práticas que aprenderam em suas famílias. Essa devoção familiar se processa em termos de um compromisso com a Virgem, mas também com as tradições locais e com os próprios laços de parentesco. A lógica do compromisso que permeia essas relações, no entanto, não é necessariamente homogênea, mas se constitui em práticas genericamente (ainda que também étnica e politicamente) marcadas. Assim, através de certas práticas de devoção, veremos como as experiências religiosas e de gênero relacionam-se e se constituem mutuamente: aprende-se a ser, ao mesmo tempo e desde o início, mulher e devota, homem e devoto.

\section{Os peregrinos da Virgem}

Graciela é uma correntina de 42 anos, casada com Vicente, dois anos mais novo. Trabalha como governanta para uma família de classe alta e, segundo deu a entender insistentemente, é o principal sustentáculo moral e econômico do seu núcleo familiar, já que, além de mãe e esposa, contribui com o maior salário para a economia doméstica. Vive num bairro da Grande Buenos Aires ${ }^{3}$ com Vicente, que é seu segundo marido e pai de Diego (18)

\footnotetext{
${ }^{3}$ Trata-se de um bairro de conjuntos habitacionais, construído há mais de 20 anos como um programa de residências baratas para classes populares no distrito de Ciudadela (Grande Buenos Aires), mas que hoje é comumente conhecido como "Forte Apache", devido à
} 
e de Cecilia (15), e com seu filho mais velho, Alejandro (25), sua nora e sua neta de cinco anos.

Freqüenta a festa da Virgem de Itatí em julho, "desde sempre", com sua família, que é nativa da zona. Mas não deixou de participar anualmente da festa nos últimos sete anos depois de curar-se de uma anorexia nervosa, "graças à Virgem". O da festa é um momento de reencontro e de celebração familiar. Embora a mãe de Graciela more no mesmo bairro que ela e sua prima Nelly a visite assiduamente, a ruptura temporal que a festa abre no ano secular renova, redefine e celebra os laços familiares através da ligação com a Virgem. Essa ligação é reconhecida por Graciela como uma herança familiar: a devoção à Virgem de Itatí que lhe vem dos seus pais e que quer deixar como legado também para seus filhos:

A mim me ensinaram meus velhos... Ou seja, eu começei a acreditar nela pelos meus velhos... Porque eles, a vida toda, era a Virgem de Itatí, sabe? Você não via outra coisa... Eles te faziam ver essa imagem... (...) $\mathrm{E}$, bem, eu acho que isso mesmo que me ensinaram meus velhos, eu estou ensinando a eles [seus filhos], porque meu filho, viu, até o mais velho, outro dia veio e a primeira coisa que fez, voôu para a igreja...

Ao contrário daqueles parentes e amigos que permaneceram "no torrão", Graciela tentou a sorte na Capital Federal e teve êxito, que manifesta nos gastos que faz na festa. Pois, embora se hospede na casa simples de sua prima Nelly, ela convida para comer fora e compra alguns itens que poderiam ser considerados de luxo, como refrigerantes ou comida pronta. Os gastos não são medidos, e Graciela, a de maior poder aquisitivo, num gesto entre a ostentação e a justiça redistributiva, convida e paga as passagens para os seus pais aposentados e leva lembrancinhas para os que não conseguiram viajar. Ao mesmo tempo, Nelly abriga, em sua casa de Itatí, todos os parentes e amigos durante os dias da festa. Assim, seguindo a Bourdieu (1999), também em momentos extraordinários como é a festa da Virgem de Itatí, são as mulheres as encarregadas de manter a solidariedade e a união familiar, sustentando as relações de parentesco, papel, segundo este autor, fundamentalmente feminino: Graciela, seu pais e Nelly moram no mesmo conjunto habitacional e se visitam diariamente, mas é na festa que os laços de solidariedade e o capital social da família (Ibid., p. 116) são redefinidos e fortalecidos.

Da mesma maneira que as mulheres pentecostais analisadas em pesquisas anteriores (Machado, 1999; Machado e Mariz, no prelo), Graciela

periculosidade de alguns de seus moradores e à quantidade de crimes que ocorrem ali. Graciela demorou um ano para me dizer onde vivia, e quando o fez não foi sem certa vergonha, dando conta que conhecia o estigma que pesa sobre os moradores do bairro. Seguidamente esclareceu que não gostava do bairro, que era perigoso e "feio", e que estava tratando de se mudar dali. 
enfatiza, como dom da Virgem, a prosperidade alcançada com seu trabalho. E não deve parecer estranho que isso aconteça, se lermos transversalmente as adesões religiosas: a lógica da prosperidade - que ganhou um status teológico no Pentecostalismo - está presente nos setores populares (cf. Semán, 2000), embora no caso católico tenha uma base institucional muito mais frágil. Graciela, que se constrói na festa como mulher urbana e afirma que trabalha porque quer sua "independência" financeira, contribui com o maior ingresso para a família, e não o esconde - como poderiam fazê-lo outras mulheres de setores populares, com vergonha - mas o declara e exibe, ao se permitir desfrutar de suas férias em Itatí "sem ter que pedir nada a ninguém".

Graciela constrói uma cadeia devocional através da qual reúne dois dos seus filhos numa promessa à Virgem, promessa que, ademais, será o eixo a partir do qual sua filha Cecilia conhecerá a Santa e sobre o qual ela vai crescer como devota. Cecilia tem 15 anos e estuda num colégio privado do bairro. ${ }^{4}$ De maneira semelhante à sua mãe, ela se encarrega de esclarecer que não tem uma prática católica regular (não tem práticas sacramentais institucionalizadas) e que "às vezes" reza. Embora ela use certos recursos que a Igreja disponibiliza, sua prática é bastante autônoma, ainda que não necessariamente individualizada. No entanto, e mais importante ainda, sua vida aparece marcada pela devoção à Virgem de Itatí, como veremos em seguida.

Rodolfo é professor de uma escola primária na zona rural de San Luis del Palmar. Define-se como um "homem a cavalo" e faz desta identificação questão de orgulho. Sua fala lenta, pausada, cheia de uma musicalidade caracteristicamente correntina parece confirmá-lo. Está casado há mais de 20 anos com Marta, também professora rural, com quem teve quatro filhos. As duas filhas mulheres, de 18 e 19 anos, têm Itatí como segundo nome, em honra à Virgem. E o nome dos dois homens, de 14 e 17 anos, é Luiz, "por São Luizinho", explica Marta. Essa prática de dar aos filhos o nome do santo ou da virgem de devoção, no intuito de ligar uma pessoa a um santo e colocá-la sob a sua proteção, é bastante comum nessa região e tem uma longa história dentro do catolicismo (cf. Brown 1981, p. 58).

A trajetória religiosa de Rodolfo e Marta tem bastante de devoção familiar, centrada no culto à Virgem de Itatí e aos santos locais, São Luiz e

\footnotetext{
${ }^{4}$ Em Buenos Aires (Capital e Grande Buenos Aires) existem numerosos estabelecimentos educacionais privados, com níveis de oferta de serviços educativos e preços de mensalidades muito diferentes. $\mathrm{O}$ fato de que Cecilia freqüente um deles indica uma valorização do capital cultural que seria dado por um título de colégio secundário, e algum tipo de ascensão social em relação à trajetória de seus pais, mas não a coloca numa situação muito diferente de outras meninas de classes populares que freqüentam escolas públicas.
} 
Santo Antonio. Com suas famílias aprenderam a rezar, conheceram a virgem e os santos e começaram a peregrinar a Itatí. E é essa mesma prática que tentam transmitir a seus filhos. Marta e Rodolfo também contam promessas. Rodolfo cumpriu sua promessa de ir caminhando de São Luiz a Itatí tão logo se formasse como professor. Marta, de sua parte, cumpriu com a promessa de ir caminhando a Itatí com a peregrinação de sanluiseños durante três anos consecutivos, em ação de graças pelo restabelecimento de seu pai.

Para eles, a ação dos santos é lida como a possibilidade, a permissão, a ajuda divina - menos extraordinária que necessária - para que as coisas boas aconteçam, ou as más deixem de acontecer. Assim, Marta e Rodolfo contam que tudo que têm e que conseguem são graças "que nos dá a Virgem, que nos dá San Luisito... de Jesus, de todos os santos...".

Além disso, há uns anos atrás, foram "tocados por Deus, escolhidos", conforme conta Rodolfo, para fazer um Cursilho de Cristandade, ${ }^{5}$ onde aprenderam "a conhecer Jesus", a quem, até esse momento, "não lo conhecim tanto quanto a Ela" (à Virgem de Itatí). Atravessado por uma vivência mais eclesiastizada, Rodolfo participa da festa de maneira diferente daqueles que, como Graciela, desfrutam o baile, as férias e as comidas: sua experiência é muito mais introspectiva, enfatizando a reflexão, quando diz que aproveita a ocasião para "pensar". Seu desfrute está, também, naquilo que aparentemente não faz durante o ano: passar tempo com sua família, dormir sem horário, cuidar dos cavalos e seus arreios. Mas, além disso, e antes de mais nada, ele é um "peregrino", e sua vivência da festa passa fortemente pela peregrinação, como veremos em seguida.

\section{Crescendo devota: uma promessa marcada pelo gênero}

Conta Graciela que quando seu filho Diego tinha cinco anos caiu acidentalmente, bateu muito forte com a cabeça e fraturou o crânio. Seu estado era muito grave e os médicos não eram otimistas em seus prognósticos, pressagiando terríveis sequielas neurológicas que iriam se manifestar com os anos. Pedindo pela recuperação de Diego, Graciela prometeu à Virgem de Itatí o cabelo de Cecilia, que então tinha um ano de idade. Ela não poderia cortá-lo até fazer 15 anos e, em seguida, quando decidisse fazê-lo, deveria entregá-lo à Virgem.

\footnotetext{
${ }^{5}$ Trata-se de cursos de catequização para adultos, geralmente diferenciados por gênero, de tendência conservadora dentro do catolicismo.
} 
Diego se restabeleceu e Graciela não se cansa de elogiar a inteligência de seu filho, dizendo, como exemplo paradigmático de sua capacidade intelectual, que ele é "um gênio com os computadores", dando a entender que a Virgem não só "cumpriu" em não deixar nenhuma seqüela, mas que teria multiplicado sua capacidade.

$\mathrm{Na}$ perspectiva da sensibilidade católica popular, a promessa e os milagres integram uma "certa ordem do mundo, fazem parte do ser-aqui. (...) a ordem das coisas é feita de dons recíprocos, e é precisamente essa troca que mantém e restaura o equilíbrio vital" (Sanchis, 1997, p. 116). Longe de ser um fato excepcional, o milagre é "um acontecimento necessário, acessível, rotineiro e reordenador" (Brandão, 1980, p. 132) na vida de Graciela. Pois, dentre os milagres que ocorreram em sua vida, pode contar não só que Diego foi "curado" graças à Virgem, mas também sua irmã e ela mesma. Também "graças à Virgem", e porque "Deus aperta, mas não enforca", ganhou uma pequena soma de dinheiro no bingo quando mais precisava. Assim, "o milagre popular é a mostra de efeitos simples de trocas de fidelidades mútuas entre o sujeito e a divinidade, com ajuda ou não de uma igreja e de mediadores humanos ou sobrenaturais. Ele não é a quebra, mas a retomada 'da ordem natural das coisas' na vida concreta do fiel, da comunidade ou do mundo, por algum tempo quebrada..." (Brandão, 1980, p. 131). É na colaboração quase mancomunada entre homens e santos que as graças e os milagres são possíveis. Ao mesmo tempo, a promessa, na lógica desses devotos, é definida pelo sacrifício. Um sacrifício que deve ser maior quanto maior for o pedido. E representa um compromisso que deve ser respeitado para poder manter a confiança do santo, o que permitirá, ao bom pagador, um crédito sempre aberto.

O milagre da cura de Diego, pedido por Graciela em troca do cabelo de Cecilia, criou um laço de fidelidade "familiar" com a Virgem: o pagamento da promesas restabeleceu uma ordem cósmica que não era alheio à esfera familiar, mas se efetivizava nela. O corpo, como "lugar de sofrimento e de salvação, como instrumento de penitência e de cura" (Steil, 1998, p. 102) e também como lugar de ruptura e restabelecimento da ordem cósmica, não é o mesmo neste caso: Diego foi quem sofreu uma grave queda que comprometia sua saúde e seu bem-estar futuro. Cecilia é quem conserva seu cabelo intacto, porque afinal de contas não é dela, mas da Virgem de Itatí.

Estes dois corpos que se encontram, um como beneficiário e outro como pagador, pela lógica do sangue e em relação a Graciela, são um. Sangue do mesmo sangue, e somente dentro desta lógica se entende por que foi Cecilia, e não Alejandro (fruto de um casamento anterior), que pagou a promessa. Sangue do mesmo sangue, Graciela reforça o laço não só entre os filhos do mesmo pai entre si e com ela, mas, além disso, entre eles três e a 
Virgem de Itatí. A promessa, ato de compromisso "voluntário" de Graciela, ao devotar o cabelo de Cecilia se converte "num assunto familiar, que todos os implicados [Graciela, Cecilia e Diego], de forma direta ou indireta, deviam assumir" (Prat, 1989, p. 229, tradução minha) e que ganha inteligibilidade em termos de um tipo de relação que não se definem como individuos modernos, mas dentro de uma tríade "família-pessoa-nome" (Viveiros de Castro e Araújo, 1977, p. 153).

Ao mesmo tempo, uma diferença de qualidade moral, marcada pelo gênero, faz com que Graciela escolha sua filha e não ao filho mais velho para cumprir a promessa. Para ela: "Alejandro é muito retobado [rebelde], não serve para isto, não chegaria ao final [do prazo prometido]". E como, na lógica do intercâmbio com o sagrado, cumprir é fundamental devido às conseqüências que poderia acarretar não fazê-lo, Cecilia, simplesmente pelo fato de "ser mulher" seria a pagadora perfeita, segundo seu ideal de feminilidade: abnegação, capacidade de sacrifício, paciência - qualidades que a própria Graciela inclui entre as suas.

Cecilia não só "herdou" da sua mãe a devoção à Virgem, também cresceu, ao mesmo tempo, como mulher e como devota. Sua passagem à vida adulta foi, da mesma maneira, ao mesmo tempo como mulher e como devota.

A procissão que culminou com o pagamento da promessa marcou uma passagem na vida de Cecilia. Por causa dela, a jovem não podia ir ao santuário num dia de festa até completar seus 15 anos. E quando o faz, deixa a infância ao adquirir a responsabilidade de pagar uma promessa, definindo-se como adulta, ao deixar de lado seu "cabelo de bebê" para tomar uma decisão como mulher:

...eu já tinha assumido. E foi essa decisão... e, bom, eu pensei em tudo o que tinha acontecido... E, bem, era uma decisão que tinha que ser tomada por mim... Não podia ser tomada por ela Graciela, nem ninguém. Era minha. Eu até que podia cotinuar com meu cabelo comprido, mas não...

Nem toda peregrinação implica um ritual de passagem, mas existem algumas que funcionam como limiares (cf. Van Gennep, 1960) na vida dos fiéis. Num livro já clássico, V. e E. Turner (1978) faz distinções entre fenômenos liminóides (opcionais, voluntários) e fenômenos liminares (mecanismo social obrigatório para marcar a transição de um estado a outro). O caso de Cecilia é liminar, pois marca uma passagem em sua vida: cumpre uma promessa e ao assumir essa responsabilidade deixa a infância, se faz mulher.

Pude encontrar casos similares de peregrinação como fenômeno liminar entre os jovens que entrevistei em Itatí. Entre os 12 e 13 anos, eles deixam 
de ir ao santuário com seus pais usando algum meio de transporte para irem a pé com seus pares: irmãos mais velhos, primos, amigos. O ritual se completa somente no ano que conseguem completar a peregrinação caminhando com seu grupo, de Corrientes até o santuário. Os homens de São Luiz do Palmar, como veremos em seguida, também passam por uma espécie de ritual de passagem no dia que são iniciados — "feitos peregrinos", segundo a definição êmica — como peregrinos a cavalo.

Cecilia cumpriu uma promessa que envolvia um laço de família: prometida por sua mãe para seu irmão. Este fato também define a relação com sua mãe. Antes disto, Cecilia e Graciela não tinham uma boa relação. Em 1998, durante a viagem de 14 horas que nos levou a Itatí, Graciela se queixava da "rebeldia" de sua filha mais nova, insistindo em que se "portava mal", nas "faltas de respeito" de sua filha para com ela, em que não fazia caso de seus conselhos ou de suas ordens. No ano seguinte, na peregrinação, a própria Graciela admitiu que sua relação tinha melhorado, que já eram "bastante amigas". O fato de terem ido juntas à festa foi fundamental, afiançando o laço que as une. Neste sentido, o laço mãe-filha se renova e se reforça ao compartilharem, no pagamento da promessa, o laço que unia, ambas, à Virgem de Itatí: uma como promitente, a outra como pagadora, e as duas uma, sangue do mesmo sangue.

Atualmente Cecília está envolvida numa nova promessa: ela vai peregrinar desde a cidade de Corrientes até Itatí assim que a Santa atender seu pedido. Ela não me contou de que se tratava, mas afirmou que não era para ela o pedido à Santa. Assim como na primeira ocasião, Cecília atua como mediadora com o sagrado para que uma terceira pessoa obtenha uma graça repetindo, mais uma vez, o modelo católico de mediação feminina com o sagrado do qual a própria Virgem é padrão.

\section{Religião é "coisa de homens": os peregrinos a cavalo}

A partir do centro da praça tem-se uma vista perfeita da basílica. Olhando-se sentado no chão, a perspectiva permite apreciar a totalidade do templo, incluída a monumental imagem da Virgem da Itatí que está na cúpula. Ali, além de no interior e nas escadas, é onde a maioria das pessoas tira fotos para testemunhar sua estadia e levar uma lembrança de Itatí.

Pois bem, estavam estes quatro ginetes se aprontando para tirarem fotos quando eu cheguei. Eram de um agrupamento gaúcho ("Tomás Martinez", segundo indicava um estandarte, de madeira e bem pintado, que traziam consigo): dois homens mais velhos - um de cerca de 40 e outro de cerca de 60 - e dois jovens em seus 20. Vinham montados em três cavalos e uma 
mula e traziam, além disso, uma bandeira argentina. Três gerações tinhamse reunido para peregrinar a cavalo até a Virgem.

Primeiro, posaram os quatro juntos, sempre com a basílica ao fundo. À esquerda, um dos jovens segurava o estandarte. No centro, um dos mais velhos segurava a bandeira. Tiraram duas ou três fotos, e depois o mais velho pediu para tirarem fotos individuais. Ele foi o primeiro. Ereto, segurando as rédeas e uma chibata com cabo de prata lavrada com a mão direita, e a mão esquerda apoiada um pouco acima da cintura sobre um poncho azul celeste claro impecável. Sua postura era relaxada, dava ordens, perguntava ao fotógrafo se o santuário saía bem.

Em seguida, posou o homem de 40 anos com a bandeira. Situou seu cavalo, acomodou seu poncho, também azul celeste e também imaculado, sobre o ombro esquerdo e segurou as rédeas com essa mão, enquanto que com a direita elevava a bandeira, deixando o final do mastro (que tinha um metro) a altura do peito. Pediu que o esperassem um minuto, inspirou, levantou o queixo e, olhando um horizonte imaginário, se deixou fotografar. Fiquei pensando sobre qual seria aquele horizonte...

Em seguida, posaram os dois jovens que, à diferença dos mais velhos, vestiam o poncho, em vez de usa-lo sobre um ombro e, em lugar de botas e bombachas, usavam jeans e sapatos informais. Causou-me simpatia essa auto-afirmação "juvenil" nas peças do vestuário. Posaram mais relaxados, quase sorrindo, um segurando o estandarte e o outro a bandeira quando lhes coube a vez. Um deles, que vinha montado na mula, pediu ao fotógrafo para esperar "até que a mula pare as orelhas", o que demorou uns minutos, pois o animal parecia querer resistir às ordens de seu ginete. Ao fim, o mais velho pediu para também ser fotografado com a mula, e assim o fez. E novamente a mula demorou a tomar a posição que seu ginete considerava adequada, para a foto. Só então a mula se colocou no lugar adequado, direita e com as orelhas paradas. $\mathrm{O}$ velho tomou a bandeira ali e a colocou da mesma forma que o outro homem antes. Com o vento, a bandeira tremulava atrás de sua cabeça, o que me deu uma impressão quase épica.

Posteriormente, o homem de 40 anos foi fotografado de pé, mostrando a chibata e segurando as rédeas de seu cavalo, que estava à sua direita.

Por fim, os quatro fotografaram-se de pé, junto de seus animais, com a bandeira e o estandarte e a igreja como fundo. $\mathrm{O}$ mais velho pediu que $\mathrm{o}$ fotógrafo repetisse a tomada, "pelas dúvidas".

Quando acabaram a sessão de fotos partiram, rodeando a praça. Passaram antes na frente da basílica, os quatro emparelhados, em pequeno trote. Ao passarem pela porta, abaixaram levemente a cabeça e se 
persignaram. Uma mulher gritou: "Olha ai!! Tira uma foto deles!! Tira! Tira!!”. E sua filha adolescente correu com a máquina na mão e disparou duas ou três vezes. Os quatro ginetes, imutáveis, continuaram sua marcha. (Diário de campo, 15/7/00)

Esse breve instante de inclinação e persignação, esses dois segundos de reverência, o tirar o chapéu ao entrar no templo e, mais evidentemente, as lágrimas silenciosas, mas indisfarçáveis, de muitos destes homens no momento de encontrar a santa invertem a postura orgulhosa que os ginetes representaram para a foto. Da mesma forma que os Cavaleiros de Bom Jesus, de que fala Fernandes (1982), essa imagem de masculinidade refletida na postura altiva se feminiza em seus gestos ao chegar aos pés da Virgem.

Mas, além disso, e combinado com o anterior, a imagem de altivez ostensiva, esse mesmo orgulho que em outro contexto seria ofensivo, é talvez a melhor oferenda que estes homens doam à Virgem de Itatí. Os arreios luxuosos, o poncho impecável, a chibata de prata e couro cru lavrado, marcas de distinção - frente ao restante dos peregrinos e frente a outros ginetes menos abonados - são a melhor oferenda que eles podem lhe dar.

Ainda que enunciá-lo pareça uma obviedade, ser peregrino de São Luiz del Palmar, mais do que qualquer outra coisa, é ser peregrino de São Luiz del Palmar. Como eles mesmos afirmam "todo o povoado peregrina" e peregrinam como povoado.

Os peregrinos de São Luiz do Palmar (província de Corrientes) cobrem os quase 70 quilômetros entre seu povoado e Itatí como uma grande maré de homens, carroças, automóveis e cavalos, que durante um dia e meio atapetam longos trechos da rodovia nacional 12. Saem de São Luiz no 13 de julho e, com exceção das paradas obrigadas para comer e dormir, o movimento ininterrupto segue o ritmo dos peregrinos a pé. Ainda que a distância que separa as duas cidades poderia completar-se andando em menos de um dia, o ritmo que manda a tradição impõe paradas previamente estipuladas, fazendo com que o trajeto - de ida e de volta - se alargue a um dia e meio.

$\mathrm{Na}$ festa de Itatí são os "sanluiseños" ou os "peregrinos de São Luizinho", numa dupla atribuição local e de padroeiro, que jogam como sinônimos intercambiáveis. Embora cada um possa participar da peregrinação por motivos pessoais ou devido a promessas individuais, o fato de participar da peregrinação centenária dos sanluiseños modifica completamente a experiência ao ser integrada numa vivência da comunidade local, chegando ao ponto de não ter sentido, para eles, peregrinar em outras ocasiões. 
Para os sanluiseños existem várias maneiras de peregrinar a Itatí. Os que vão a pé, considerados "os mais sacrificados" são, geralmente, pagadores de promessas. Os veículos, em geral, transportam mulheres, idosos e crianças pequenas, além de todos os utensílios necessários para as cinco jornadas de travessia e estadia em Itatí. As carroças, ainda que permaneçam valorizadas porque são "tradicionais", pertencem - segundo contam os sanluiseños aos peregrinos mais pobres. Portanto, são os ginetes - porque à diferença das carroças, não estão associados à pobreza - que se consideram os portadores da tradição centenária de peregrinar a Itatí: sem ir mais longe, Rodolfo comentou, enfático, que aquele ano havia "mais de três mil ginetes", mas não mencionou nem o número de carroças, nem a quantidade de caminhantes. Emblemático era o número de ginetes.

"Fazer peregrinos" e "se fazer peregrino" é, especificamente, fazer e se fazer um peregrino a cavalo. Por mais que anteriormente se tenha participado por qualquer outro meio - inclusive caminhando - ir a cavalo implica uma passagem, uma mudança de status, um ato ritual que envolve uma consagração (cf. Fernandes, 1982) e a adesão a um compromisso que os envolve como partes de um todo: eles são os peregrinos de São Luiz.

Ao "fazerem-se peregrinos", também se fazem sanluiseños, porque se tornam parte dessa peregrinação em particular. E esta tradição local, viabilizada por meio dos homens da família, começa a partir de um convite, que no caso de Rodolfo veio de seu sogro:

Minha família, no caso do meu pai, não eram, assim, peregrinos... Quem me fez peregirno desse jeito foi a família da minha esposa. Eu era, sim, sempre devoto da virgem. (...) E foi assim que uma vez, porque não quis dirigir um caminhão que tinha [para a peregrinação], me convidaram a vir a cavalo e eu vim, vim com vontade.

Embora Rodolfo tivesse peregrinado antes com sua família, por outros meios, ele marca sua iniciação como peregrino a partir da primeira vez que chega a Itatí a cavalo, convidado pelo sogro. Assim, "fazer peregrinos" é uma tarefa de homens para homens, entre homens. Antigamente, somente os homens peregrinavam a cavalo, e as mulheres caminhavam ou chegavam em algum veículo. "A cadeia", como a define Rodolfo, é construída com elos masculinos:

E fiz ele seu filho mais velho peregrino, trazendo-lhe das rédeas, porque era muito pequeno, tinha cinco anos... E depois fiz meu outro filho homem... E depois trouxe sobrinhos... Uh, que eu fiz peregrinos! (...) Isso que temos, os peregrinos mais velhos, de continuar a fazer peregrinos...

Atualmente, várias mulheres - majoritária, ainda que não exclusivamente, de classe média e alta, solteiras e jovens — também 
cavalgam. Sua presença, seu porte e sua vestimenta lembram as praticantes de hipismo. As filhas de Rodolfo, por exemplo, cavalgam na peregrinação há cinco anos, mas ele nunca se referiu a elas como "peregrinas". As filhas adolescentes de Antonio, outro peregrino que leva o nome do padroeiro da sua cidade natal, ${ }^{6}$ chegaram a Itatí a cavalo em 1998 e 1999, mas faltaram em 2000 e isso não o inquietou. Neste sentido, as mulheres têm a possibilidade de não criarem o compromisso de cavalgar sempre e em nenhum caso estão obrigadas a continuar cavalgando anualmente. Embora não vá me deter neste ponto, pois uma análise profunda disto requereria participar da peregrinação, é necessário observar que, dentro da peregrinação de São Luiz, a presença de mulheres montando a cavalo, considerando o que implica "ser peregrino" para os sanluiseños em termos de valorização de um determinado tipo de masculinidade, é uma inovação que não deixa de ser interessante e chamativa e nos lembra que as tradições estão vivas e que incorporam elementos novos, ao mesmo tempo que, aparentemente, permanecem iguais a si mesmas.

Os homens, de sua parte, quando têm que abandonar o cavalo - seja porque nesse ano não conseguiram um, seja porque, na falta de outro motorista, têm de dirigir algum automóvel com os utensílios — não deixam de expressar seu descontentamento, pois têm de se encarregar de uma atividade mais doméstica (e por conseguinte mais feminina e subalterna), como a de se encarregar de conduzir o veículo que leva o necessário para a sobrevivência. O compromisso criado quando um homem "se faz peregrino" é, ao mesmo tempo, com a Virgem e com a própria peregrinação.

Você tem que vir porque é peregrino e seu cavalo está lhe esperando. Você tem que vir.

Esse foi o argumento que Mariana Itatí, sua irmã mais velha, esgrimiu diante de Juan Luiz, o mais velho dos filhos homens de Marta e Rodolfo, que estuda na cidade de Rosario (província de Santa Fé). O jovem duvidava conseguir permissão para faltar ao colégio e assistir à festa da Virgem. A interpelação de sua irmã para que superasse os obstáculos e conseguisse viajar não era algo menor. Era uma questão de honra à qual não se podia faltar.

Por outra parte, a quantidade de pessoas que um homem mobiliza, seja iniciando peregrinos, seja emprestando os cavalos, diz de sua devoção pela Virgem, na medida que cada novo peregrino é ofertado a Ela. Isto gera não pouca emoção naqueles que, como Rodolfo, são os iniciadores. Não só

\footnotetext{
${ }^{6}$ Santo Antônio de Pádova é o padroeiro de Mburucuyá (Província de Corrientes), mas não é o único santo Antônio que empresta seu nome a devotos e filhos de devotos: muitos o devem a Antonio Gil ou "el gauchito Gil" (cf. nota 8).
} 
porque nessa passagem os novos peregrinos adquirem algo que os define como "cavaleiros", síntese de um ideal de masculinidade, mas também porque cada novo peregrino é uma oferenda que eles fazem à Virgem de Itatí.

Eu, por exemplo, trouxe meu filho. Chorei, lacrimejei porque... você sabe que é seu filho e que é a primeira vez, a experiência... Depois trouxe sobrinhos, a mesma coisa: uma emoção... Depois trouxe amigos, porque a gente vai fazendo e parece que sente uma satisfação interior de fazer um novo peregrino...

E nos diz também de um orgulho local pela tradição centenária de peregrinar, que se vê incrementada com os novos peregrinos:

E depois, como a gente é peregrina... a gente tem orgulho da sua cidade ou de seu povoado, então também se trata de fazer o melhor, não é verdade? Para que seu povoado e sua peregrinação sejam assim, que seja lindo... A cada ano vamos colocando o melhor para, como estou lhe falando, ser orgulhoso de nossa peregrinação... (...) Com mais orgulho, posso lhe dizer que não acredito que tenha outra no mundo. Já estão comentando, viu, que o [vídeo] cassete da peregrinação percorreu o mundo, e ficam admirados...

Para os ginetes, a oferenda à Virgem de Itatí combina o sacrifício da cavalgada, os gestos de inversão e aquilo que lhes é mais caro e que constróem não sem esforço: a altivez. Uma altivez que, devido aos valores com que está carregada - holismo, hierarquia (Semán, 2001) — não compete com e não questiona a autoridade divina. Ao contrário, procura mostrar as melhores características de uma determinada concepção de pessoa, para estar "à altura". Uma altivez que é produto do orgulho de "ser da Virgem e de São Luizinho", antes que uma tentativa de inverter os planos, colocando homens acima de divindades. Uma altivez que é representativa de um ideal de gaúcho construído como arquétipo nacional, ao mesmo tempo que correntino. ${ }^{7}$ Enquanto, no caso do Rio Grande do Sul (Brasil), o gaúcho aparece como um tipo particular — regional — de nacionalidade (Oliven, 1992), em Corrientes, o gaucho ganha uma particularidade - provincial — do tipo nacional. Se o gaucho, na Argentina, é apresentado como emblema da nação, em Corrientes, ganha as características diferenciais desta província: ele pode ser correntino, porque antes é argentino.

7 Tal como afirma Nicolás Shumway (1995), autores como Bartolomé Hidalgo, Ricardo Güiraldes, Lucio V. Mansilla e José Hernandez construíram o gaucho - por meio da poesia gauchesca - como uma das principais "ficções orientadoras" da nacionalidade, símbolo genuíno da nação emergente, imbuído de qualidades míticas que encarnam o espírito nacional. Estes autores, que escrevem em finais do século XIX e começos do século XX, plantam as bases de uma ficção orientadora populista, como propõe Shumway (1995), antes mesmo de começar o processo de nation-building na Argentina, a partir de 1880, pois Hidalgo publica seus primeiros versos durante a década independentista (1810-20). 
Todavia, os de San Luiz del Palmar não são os únicos gauchos no santuário e na festa: também estão os devotos do Gauchito Gil. ${ }^{8} \mathrm{O}$ mesmo ideal de masculinidade, caracterizado pela combatividade, a força, a coragem e a altanaria, se condensa nesse santo local que, representado por seus devotos, também reverencia à Virgem em sua festa. Para eles a experiência da peregrinação envolve um componente de correntinidade, que é construído a partir de uma lógica que não é necessariamente política, ainda que, sim, fortemente territorial. A peregrinação a Itatí encarna uma prática devocional transmitida por meio dos laços familiares - como vimos com Rodolfo - e que, ao mesmo tempo, define muito fortemente o pertencimento a uma comunidade.

Desta maneira, esses homens se afirmam e, ao mesmo tempo, se oferecem como correntinos, construindo uma imagem de gaucho mítico, que supervaloriza certas características de masculinidade, as mesmas que depois oferecem à Virgem. Homens autônomos ${ }^{9}$, sua devoção e o sacrifício que oferecem não requerem necessariamente mediação eclesiástica. Embora quase todos entrem no templo para "ver a Virgem", nem sempre participam dos rituais. Sua própria presença, devidamente vestidos e com seus cavalos engalanados, já constitui um ato de profunda devoção, é um ritual em si mesmo.

\footnotetext{
${ }^{8}$ As notícias históricas sobre a vida de Antonio Gil são relativamente incertas ou variáveis, ainda que a maioria das versões coincida em afirmar que ele teria vivido em Corrientes na segunda metade do século XIX. Gil era um gaúcho que, como boa parte dos moradores pobres da região, viveu de atividades vinculadas à produção pecuária, às vezes como peão, às vezes como ladrão de gado. Os relatos assinalam que sua morte se deu nas mãos das tropas provinciais ou dos fazendeiros que o perseguiam devido aos roubos de animais e que resultavam em benefício dos mais pobres. Essas narrações coincidem no fato de que sua morte foi precedida por pedidos de clemência do gaúcho e por promessas de retribuir seus captores com poderes sobrenaturais, que, no caso de ser condenado a morrer, obrariam numa vingança. Sua execução, apesar da inocência que o relato lhe reconhece, foi completada com detalhes de crueldade especial: o degolamento e o abandono do cadáver insepulto. No entanto, seus próprios executores, num ato de arrependimento que é imputado a milagres atribuídos ao gaúcho, puseram uma cruz no lugar de sua morte, consagrando, assim, um espaço que depois foi privilegiado pelas práticas religiosas da população local. A sede principal desse culto, além de seu túmulo em Mercedes (Corrientes), é constituída pelos altares erigidos em lares de bairros populares em toda a província e, pude observar, também em bairros de Buenos Aires e Grande Buenos Aires. Neles, são realizadas cerimônias religiosas nos dias 8 de cada mês, assim como as festas que comemoram sua morte no dia 8 de janeiro de cada ano. Até aí acodem os devotos para realizarem seus pedidos e testemunharem seu agradecimento (cf. Coluccio, 1986; Castelli, 1995; Zinni, 1984).

${ }^{9}$ Honra, autonomia, coragem, são alguns destas características. No seu artigo baseado nos casos de Uruguai e Rio Grande do Sul, Leal (1992) enfatiza a exibição ostensiva dessas mesmas qualidades como ideais de virilidade para a cultura gaúcha.
} 


\section{A modo de conclusões}

Nos casos aqui analisados, a devoção à Virgem é atravessada pela lógica do compromisso e a experiência da festa é definida por laços familiares genericamente marcados e pelos costumes que passam de pais a filhos. Esta implica difundir um certo tipo de catolicismo aos filhos próprios e aos alheios, porque é um valor que tem a ver não só com os laços de parentesco, mas com a tradição local.

E ainda mais: a experiências religiosa e de gênero são constitutivas do self de forma associada. Aprende-se a ser mulher através de uma promessa, tanto quanto se aprende que através de alguns gestos - abnegação, paciência e também trabalho - pode-se obter um milagre da Santa. Aprende-se a ser homem cavalgando em peregrinação, tanto quanto se aprende que a Virgem não perdoa àqueles que falham num compromisso.

É na própria relação com o sagrado - em cada prática singular - que cada um se define como masculino ou feminino, independentemente do conteúdo que esses termos adquiram em cada caso. E é através da própria experiência de gênero - performática e contextual - que cada um se relaciona com o sagrado.

\section{Referências}

BOURDIEU, Pierre. A dominação masculina. Rio de Janeiro: Bertrand Brasil, 1999.

BRANDÃO, Carlos Rodrigues. Os deuses do povo: um estudo sobre a religião popular. São Paulo: Brasiliense, 1980.

BROWN, Peter. The cult of the saints: its rise and function in late Christianity. Chicago: University of Chicago Press, 1981.

CASTELLI, Eugenio. Antología cultural del litoral argentino. Buenos Aires: Ediciones Nuevo Siglo, 1995.

COLUCCIO, Felix. Cultos y canonizaciones populares de la Argentina. Buenos Aires: Biblioteca de Cultura Popular, 1986.

FERNANDES, Rubem César. Os Cavaleiros do Bom Jesus: uma introdução às religiões populares. Primeiros vôos 7. Brasília: Brasiliense, 1982.

LEAL, Ondina Fachel. Honra, morte e masculinidade na cultura gaúcha. In: TEIXEIRA, Sérgio Alves e ORO, Ari (orgs.). Brasil \& França: ensaios de Antropologia Social. Porto Alegre: Editora da Universidade Federal do Rio Grande do Sul, 1992, p.141-150.

MACHADO, Maria das Dores e MARIZ, Cecília. Mujeres en tres grupos religiosos en Brasil: una comparación entre pentecostales y católicas. In: MARCOS, Sylvia (org.). Enciclopedia Iberoamericana de las Religiones. Vol. Género y religión. Madrid: Editorial Trotta, (no prelo). 
MACHADO, Maria das Dores. S.O.S. mulher: a identidade feminina na mídia pentecostal. Ciencias Sociales y Religión/ Ciências Sociais e Religião, Porto Alegre, v.1, n. 1, 1999, p. 167-188.

MARTÍN, Eloísa. "Genuinamente correntina": um estudo antropológico da experiência católica na festa da Virgem de Itatí. Porto Alegre, 156 p. Dissertação (mestrado). Programa de Pós Graduação em Antropologia Social, Universidade Federal do Rio Grande do Sul, 2001.

OLIVEN, Ruben. A parte e o todo: a diversidade cultural no Brasil-Nação. Petrópolis: Vozes, 1992.

PRAT, Joan. Los santuarios marianos en Cataluña: una aproximación desde la etnografía. In: SANTALÓ, Carlos; BIXÓ, María Jesús e RODRIGUEZ BECERRA, Salvador (coords.). La religiosidad popular. v. III Barcelona: Antrophos, Editorial del Hombre y Fundación Machado, 1989, p. 211-252.

SANCHIS, Pierre. Da quantidade à qualidade. Como detectar as linhas de força antagônicas de mentalidades em diálogo. Revista Brasileira de Ciências Sociais, v. 12, n. 33, 1997, p.103126.

SEMÁN, Pablo. A "fragmentação do Cosmos": um estudo sobre as sensibilidades de fiéis pentecostais e católicos de um bairro da Grande Buenos Aires. Porto Alegre, 381 p. Tese (doutorado). Programa de Pós-Graduação em Antropologia Social, Universidade Federal de Rio Grande do Sul, 2000.

SEMÁN, Pablo. Cosmológica, holista y relacional: una corriente de la religiosidad popular contemporánea. Ciencias Sociales y Religión/ Ciências Sociais e Religião, Porto Alegre, v. 3, n. 3, 2001, p. 45-74.

SHUMWAY, Nicolas. La invención de la Argentina: historia de una idea. Buenos Aires: Emecé, 1995.

STEIL, Carlos Alberto. Catolicismo popular tradicional e ação pastoral: desafíos e perspectivas no contexto da cultura contemporânea. In: Teocomunicação, Porto Alegre, vol. 28, n. 119, 1998, p. 87-104.

TURNER, Victor e TURNER, Edith. Image and pilgrimage in Christian culture: anthropological perspective. New York: Columbia University Press, 1978.

VAN GENNEP, Arnold. The rites of passage. London: Routledge \& Kegan Paul, 1960.

VIVEIROS DE CASTRO, Eduardo e ARAÚJO, R. Romeu e Julieta e a origem do Estado. In: VELHO, Gilberto (org.). Arte e Sociedade: Ensaios de Sociologia da Arte. Rio de Janeiro: Zahar Editores, 1977, p. 130-169.

ZINNI, Julián. Memorial de la sangre: aporte para el esclarecimiento de nuestra identidad. Mercedes, Corrientes: Editorial Payubre, 1984. 